\title{
PERSONAL COST OF REPORTING AND STATUS OF WRONGDOER: EXPERIMENTAL STUDY OF WHISTLEBLOWING INTENTION
}

\author{
Claudia Vinska Vinancia ${ }^{1}$, Intiyas Utami ${ }^{1}$ and Nafsiah Mohamed $^{2}$ \\ ${ }^{1}$ Universitas Kristen Satya Wacana Salatiga, Indonesia \\ ${ }^{2}$ Universiti Teknologi MARA, Malaysia \\ E-mail: nafsiah793@uitm.edu.my
}

\begin{abstract}
Whistleblowing is an important action for the organization as a form of internal control of illegal actions that cause losses. This study aimed to test of causality of the personal cost of reporting and status of the wrongdoer on whistleblowing intention. This study used a true experimental design between subjects $2 \times 2$. The subjects of this study were 95 accounting study program students. The students acted as the government's internal auditor. The results of this study indicate that the whistleblowing intentions will be higher if the personal cost of reporting and the status of the wrongdoers are lower as compared when the personal cost of reporting and the status of wrongdoers are higher. A whistleblower prefers not to perform whistleblowing when the wrongdoer has a higher position and sanctions to be received are severe.
\end{abstract}

Keywords: personal cost of reporting, status of wrongdoer, whistleblowing intention.

\section{ARTICLE INFO}

Article History:

Received: 11 July 2019

Accepted: 4 November 2019

Published: 31 December 2019 


\section{INTRODUCTION}

Organizations are currently faced with the threat of fraud that endangers the continuity of their businesses, including in public sectors (Seda \& Kramer, 2015). One indication of fraud is the number of public servants who have a lifestyle that exceeds their capacity limits (ACFE, 2018). The public sector should provide services to the community fairly and without partiality, but officers in this sector often compromise their integrity by accepting bribes, gratuities or other types of fraud (Seda \& Kramer, 2015). Fraud includes corruption, asset abuses, and fraudulent financial statements. The most common type of fraud in the public sector is corruption with $50 \%$ of total fraud (ACFE, 2018).

Corruption is a type of fraud committed by taking money or goods that are not theirs for personal gain (Kummer, Singh, \& Best, 2015). In the PERC (Political and Economic Risk Consultancy) ranking, Indonesia ranks the second worst in Asia in the category of efficiency of public services (KPK, 2018). One of the cases of corruption in the public sector that recently happened was the procurement of e-KTP (electronic identification card) in 2017 which caused state losses of Rp 2.3 trillion and implicated the name of the House of Representative chairman, Setya Novanto. A total of 22 members of the Regional House of Representative of Malang for 20142019 period were also determined by the KPK (Corruption Eradication Commission) as the suspects related to bribery amounted of Rp. 5.8 billion in September 2018 (Wismabrata, 2018). The KPK revealed that if public sector corruption continues to happen, it will result in greater loss suffered by the nation, the decreasing level of public trust in the public sector, and inefficient public service bureaucracies.

One way to reduce fraud is through a whistleblowing mechanism (ACFE, 2018). Whistleblowing is the process of illegal or immoral action disclosure by members of the organization to people or organizations that can deal with such fraud (Gottschalk, 2011). The determinants of whistleblowing include the characteristics of the whistleblower, the characteristics of the recipient of the report, the characteristics of the wrongdoer, the characteristics of fraud, and the characteristics of the organization (Gao \& Brink, 2017). The characteristics of the whistleblower include characteristics of personality, moral judgments to assess a person's right or wrong behavior, 
and demographic characteristics, namely age, race, gender, and experience. The characteristics of the report recipient consisting of characteristics of the recipient of the report and the characteristics of the reporting channel, such as the administration. The third determining factor focuses on the strength and credibility of the wrongdoers. The characteristics of fraudulence are divided into the organization's dependence on errors, the credibility of the whistleblower's evidence, and the legality of alleged fraud that influences witnesses' perceptions and whether the report will be handled or not. The other determinants include the feasibility of whistleblowing, organizational climate, and organizational structure (Gao \& Brink, 2017).

The act of whistleblowing is important for an organization, but the decision to report fraudulence is not easy to make. The ERC (Ethics Resource Center) found that $41 \%$ employees were aware of fraud in their organization, but $31 \%$ chose not to report such actions (ERC, 2013). One of the considerations of employees is the sanctions that will be accepted after carrying out whistleblowing (Alleyne, Hudaib, \& Pike, 2013). This employees' view of sanctions refers to the personal cost of reporting. Kaplan, Pope, and Samuels (2010) define the personal cost of reporting as an employee's view of the risk of sanctions that can reduce their intention to report a fraud. Some of these sanctions can be in the form of defamation, termination of employment, or other types of discrimination.

In addition to personal cost of reporting, employees' considerations are also affected by the status of employees who commit fraud or referred to as fraudulent perpetrator status (Gao, Greenberg, \& Wong-On-Wing, 2014). Employees with low positions will find it difficult to report fraudulent actions by employees with higher positions or ranks. It is because the employees with high positions have a power to take revenge on those who report their actions. The greater the distance of the perpetrator' position or rank with the fraud reporter, the greater the likelihood that the employee who reports receives revenge (Nickolan, Handajani, \& Hermanto, 2018). Bjørkelo, Einarsen, Nielsen, and Matthiesen (2011) and Sonnier (2013) state that whistleblowing is closely related to the position of the reporting and reported employees in the company.

There are several researches regarding whistleblowing, personal cost of reporting, and the status of the wrongdoer. Craft (2013) and Alleyne et al. (2013) found that the personal cost of reporting does not affect the intention 
of employees to be a whistleblower. Morrison (2011), Kaptein (2011), and Cho and Perry (2012) conducted a study of the status of the wrongdoer and obtained results that the status of wrongdoer affected the intention of a whistleblower. Suyatno, Armstrong, and Thomas (2017) found that the status of the wrongdoer did not affect the intention of whistleblowing. Nickolan, Lilik Handajani and Hermanto (2018) found that the personal cost of reporting and the status of the wrongdoer affected the potential for whistleblowing in BPK RI.

Studies on the personal cost of reporting and the status of the wrongdoer such as those that were conducted by Kaptein (2011), Cho and Perry (2012), Suyatno, Armstrong and Thomas (2017) tend to be done in the private sector. Meanwhile, Craft (2013), Alleyne et al. (2013), Morrison (2011), Nickolan, Handajani and Hermanto (2018) conducted research in the public sector with internal auditors. Government internal auditors as part of the government internal control apparatus have an important role in whistleblowing. The Government Regulation No 60 of 2008 of Article 11 Regarding Government's Internal Control System regulates that the task of internal government auditors is to improve the effectiveness of risk management and the quality of governance in the functioning of Government Agencies. One way to improve the effectiveness of risk management and the quality of governance is through whistleblowing (ACFE, 2018).

Law No 28 of 1998 regulates the task of internal government auditors is to supervise the implementation of government affairs in the regions for the realization of a good and clean governance free from corruption, collusion and nepotism practices. Nonetheless, the practices of corruption, collusion and nepotism in the public sector continue to occur (Alleyne et al., 2013). Thus, a research on the intention of whistleblowing on internal government auditors who are influenced by the personal cost of reporting and the status of the wrongdoer has the potential to be investigated.

This study aimed to examine the causal relationship between the personal cost of reporting and the status of the wrongdoer towards the intention of whistleblowing in the public sector, so that relationships among variables have high internal validities. This study is expected to be able to contribute to the knowledgebase and understanding of audits, especially the system of whistleblowing in the public sector to reduce fraud. 


\section{LITERATURE STUDY AND HYPOTHESIS DEVELOPMENT}

\section{Research Scope}

Fraud conditions in this study are described in the context of manipulation of official travel reports carried out by the heads or accounting staff of an organization. To reveal fraud in government organizations there is a mechanism for whistleblowing that is influenced by several factors, namely the personal cost of reporting and the status of the wrongdoer. The personal cost of reporting is the received sanction after a whistleblower performs whistleblowing. This study defines the two types of personal cost of reporting, namely personal cost of high and low reporting. Personal cost of high reporting is described by disrespectful termination of employment. Personal cost of low reporting is described by sanction of reprimand. The status of the wrongdoer is also divided into two categories, namely the status of a high and a low wrongdoer. The position as the head of a health office becomes a form of high wrongdoer status. Conversely, the position as an accounting staff is a form of low wrongdoer status. The decision to be a whistleblower is obtained after accepting the condition of a high/low personal cost and high/low wrongdoer status.

\section{Theory of Planned Behavior}

The Theory of Planned Behavior reveals that a person's behavior is driven by the intention to behave. This theory is related to whistleblowing because intention has an important role in determining the act of whistleblowing (Alleyne et al., 2013). The greater the intention of someone to take action, the greater is the possibility of that intention being actualized in the form of an action. Therefore, intention will be a factor in predicting the act of someone's whistleblowing. An organization that is intended to design an effective whistleblowing system needs to understand the various factors that can affect its employee's intention to be a whistleblower (Ajzen, 2011a).

\section{Whistleblowing}

Disclosure of disgrace is defined as disclosure by a member of an organization concerning illegal or immoral actions to his fellow members 
of an organization or to an organization that can make improvements over those fraud (Gottschalk, 2011). Whistleblowing is an important action carried out by every organization as a form of internal control of any illegal action that cause losses. When we use the term whistleblowing, we are talking about reporting on misconduct by individuals or companies that take advantage of the government or cause some public harm. Whistleblowing in an organization can increase security from the threat of fraud committed by members of the organization (Gottschalk, 2011). Whistleblowing is a method of uncovering fraud that is more effective than other methods (Kummer et al., 2015).

There are two types of whistleblowing, internal and external whistleblowing. Internal whistleblowing is individual who reports suspected misconduct up the chain of command at the subject's workplace. This can involve going to an audit department, a compliance officer, a supervisor, in-house legal counsel or even an internal hot line. External whistleblowing refers to an individual who observes misconduct by an entity or individual, generally an employer, customer, supplier or competitor. Then, they report that misconduct to an outsider, generally a private attorney. Whistleblowers might report directly to a government agency or prosecutor or utilize a public hotline designed for reporting fraud or abuse by companies.

The fraudulent reporter in an organization is called a whistleblower. The whistleblower comes from the internal organization. An employee who knows the importance of the whistleblowing towards his organization is faced with an ethical dilemma as to whether to report the known fraud or to allow such fraud to remain hidden (Suyatno, Armstrong, \& Thomas, 2017). Good corporate governance is the hope of every organization. However, this expectation is sometimes constrained by human resources who do not have good integrity. Often organizational cheating practices are known by employees at the bottom first. There are several causes of fraud that are not revealed, namely because they are not formally regulated. To create good governance, a whistleblowing system is needed (Morrison, 2011). This system can reduce the risk of an organization's reputation. Reporting through whistleblowing is also useful for improvement so that similar fraud does not recur. In addition, it can improve the culture of business ethics. The whistleblowing system compared to other reporting systems will provide convenience and a sense of security for the reporter. 
To reduce this dilemma, the government has issued a law to protect a whistleblower, namely the Republic of Indonesia Law No. 31 of 2014 concerning the protection of witnesses and victims.

\section{Personal Cost of Reporting}

One of the factors that influences one's intention to be a whistleblower is the personal cost of reporting. The personal cost of reporting is explained as the employees' views on the risk of sanctions that he/she will receive when the fraud is reported (Kaplan et al., 2010). Perception of an increasingly high personal cost of reporting can reduce the intention of employees to report any fraud. Sanctions received by those employees may include: postponement in promotion, defamation, elimination of additional income, termination of employment, and other forms of discrimination (Kaplan et al., 2010). A higher personal cost of reporting will reduce the intention to perform whistleblowing (Nickolan, Lilik Handajani, \& Hermanto, 2018). The personal cost of reporting of members of public sector organizations in Indonesia may include reprimand, demotion, or even disrespectful dismissal (DJPP, 2010).

\section{Status of Wrongdoer}

Another factor that influences a person's intention to be a whistleblower in addition to the personal cost of reporting is the status of wrongdoer. The status of the wrongdoer is the status of an employee who commits fraud (Nickolan, Lilik Handajani, \& Hermanto, 2018). The status or level of power of the wrongdoer influences one's intention to be a whistleblower (Gao, Greenberg, \& Wong-On-Wing, 2014). ACFE (2018) found that 70\% of the wrongdoing in the public sector occurs at the executive or managerial level. The acts of fraud committed by members of an organization with high status will be more difficult to be reported members with a low status in an organization. The high status member of an organization through his high position has the power or authority to retaliate against those who report his fraud. This means that the greater the distance between the position and fraudulence, the greater the likelihood of retaliation will be received by the whistleblower (Nickolan, Handajani, \& Hermanto, 2018) 


\section{The Relationship between Personal Cost of Reporting and Intention of Whistleblowing}

One of the considerations for a member of an organization in carrying out whistleblowing is the sanctions that could be accepted. Sanctions may come from management, employer, or even coworkers. Taras, Kirkman, and Steel (2010) state that sanction includes measures to undermine the process of whistleblowing, exclusion, character assassination, exceptions at meetings, or other disruptions. Nickolan, Lilik Handajani and Hermanto (2018) said that the greater the risk, the greater possibility for someone to conceal what they actually know.

Craft (2013) and Alleyne et al. (2013) found that the personal cost of reporting did not affect the intention of external auditors in whistleblowing. It is because an audit practitioner must be professional and independent. This professional and independent attitude will increase management trust and not interfere with the level of objectivity of the produced reports. Unlike Craft (2013) and Alleyne et al. (2013), Nickolan, Handajani, and Hermanto (2018) also conducted a study on personal cost of reporting toward Indonesian government auditors and showed that the personal cost of reporting affected the intention to perform whistleblowing.

The attitude in the theory of planned behavior is explained as a person's actions based on consideration of gains and losses that he can obtain (Ajzen, 2011a). The intention of someone to take action will be higher when he feels that he will get benefits from his action. A whistleblower, including members of public sector organizations also tend to consider the advantages and disadvantages obtained when carrying out whistleblowing. The Government Regulation No. 53 of 2010 concerning Civil Servants Discipline regulates the personal costs of members of public sector organizations in Indonesia. The low personal cost of reporting that can be received by members of public sector organizations are reprimands, postponement of a one year salary and position, or demotion for one year. The high personal cost of reporting is demotion for three years or even disrespectful dismissal. If a sanction to be received by a whistleblower is high, it will reduce his intention to be a whistleblower. Thus, the first hypothesis is formulated as follows: 
H1: Subject with a condition of high personal cost of reporting will have a lower intention to be a whistleblower than a subject with a condition of low personal cost of reporting.

\section{Relationship between Status of Wrongdoer and Intention of Whistleblowing}

Fragale, Overbeck, and Neale (2011) stated that one's status is only as much as others give. The status of a wrongdoer is the position or authority of the wrongdoer. The status of the wrongdoer is one of the considerations for a whistleblower. The wrongdoer who has a high position will be difficult to be reported. This is caused by the consequences obtained when revealing the fraud of those with a higher authority (Nickolan, Handajani, and Hermanto, 2018). Morrison (2011) conducted a survey of the public sector and found that members of organizations that had low positions often received improper treatment. Kaptein (2011), Cho and Perry (2012), and Nickolan, Handajani, and Hermanto (2018) also said that a high-status wrongdoer would be difficult to be reported. However, Suyatno, Armstrong, and Thomas (2017) found that the position of fraudulent perpetrator did not affect the intention of whistleblowing.

A whistleblower will consider the position of a wrongdoer. The organizational structure that places the Regional Inspectorate under the Regional Head and administratively under the Regional Secretary allows a higher rate of retaliation when the fraud is reported. One category in the theory of planned behavior is the control of behavior which postulates that a person's actions depends on the ease or difficulty that they will encounter (Ajzen, 2011a). If the position of the wrongdoer is higher, then it is increasingly difficult for a whistleblower to uncover a fraud. In addition, it will be easier for a wrongdoer to take revenge on the whistleblower. It will reduce the whistleblower's intention to be a whistleblower. Therefore, the second hypothesis is proposed as follows:

H2: Subjects with a high wrongdoer status will have a lower intention to be a whistleblower than subjects with a low wrongdoer status. 


\section{Personal Cost of Reporting, Status of Wrongdoer and Intention of Whistleblowing}

The research results of Nickolan, Handajani and Hermanto (2018) show that the personal cost of reporting affects the intention of whistleblowing of civil servants. Morrison (2011), Kaptein (2011), Cho and Perry (2012) also conducted research on the status of a wrongdoer against the intention of whistleblowing. The research results indicated that the higher the position of the wrongdoer, the more the organization will depend on him. It causes the wrongdoer to act arbitrarily and the potential for retaliation is great for the informant of fraud.

Nickolan, Handajani, and Hermanto (2018) conducted a study on the effect of the personal cost of reporting and the status of wrongdoer on Indonesian government auditors. The results of the study revealed that the personal cost of reporting and the status of the wrongdoer did affect one's intention to perform whistleblowing. A whistleblower will prefer not to perform whistleblowing when he knows that the wrongdoer has an authoritive position far above him. He will choose to remain silent for he knows that he could receive very harsh sanctions.

Retaliation is an important component in the personal cost of reporting. Based on the theory of planned behavior, one's actions are based on the consideration of advantages or disadvantages and potential easiness or difficulty that could be faced (Ajzen, 2011a). A whistleblower who reports fraudulent actions committed by a wrongdoer with a high authority will meet severe sanctions. Thus, the higher the status of the wrongdoer, the higher the personal cost of reporting received by the informant and it will reduce the intention to perform whistleblowing. Based on previous arguments the third hypothesis is formulated as follows:

H3: Subjects with a condition of a high personal cost of reporting and status of wrongdoer will have a lower intention to perform whistleblowing than subjects with a low personal cost of reporting and status of wrongdoer. 


\section{RESEARCH METHOD}

This study used a quantitative method in the form of laboratory experiments. This study examined the presence of whistleblowing intention in the condition of high personal cost of reporting and status of wrongdoer. The study used data from students who have taken audit courses. The dependent variable in this study was the intention of whistleblowing and the independent variable was the personal cost of reporting and status of wrongdoer.

The experimental method was chosen because it has high internal validity in testing the relationship between the dependent and independent variables. In addition, the experimental method is able to control other variables outside the relationship. This study used the factorial $2 \times 2$ design. The first factor is the condition of the personal cost of reporting consisting of two levels, namely subjects with the condition of a high personal cost of reporting and subjects with the condition of a low personal cost of reporting. The second factor is the condition of the wrongdoer's status consisting of two levels, namely subjects with conditions of a high wrongdoer status and subjects with a condition of low wrongdoer status.

Table 1: Experimental Matrix

\begin{tabular}{cccc}
\hline \multirow{2}{*}{ High } & & \multicolumn{2}{c}{ Status of Wrongdoer } \\
\cline { 3 - 4 } & & \multicolumn{3}{c}{ Low } \\
\hline \multirow{2}{*}{ Personal Cost of Reporting } & High & Cell 1 & Cell 2 \\
\cline { 2 - 4 } & Low & Cell 3 & Cell 4 \\
\hline
\end{tabular}

Information:

Cell 1: Condition of high personal cost of reporting and high status of wrongdoer.

Cell 2: Condition of high personal cost of reporting and low status of wrongdoer

Cell 3: Condition of low personal cost of reporting and high status of wrongdoer.

Cell 4: Condition of low personal cost of reporting and low status of wrongdoer. 
Personal cost of reporting is the employee's view of the risk of sanctions that might be received after he/she reports a fraud (Kaplan, Pope, $\&$ Samuels, 2010). Status of wrongdoer is the status of an employee who commits a fraud (Nickolan, Handajani, \& Hermanto, 2018). The stages in this study are in the form of preparation of four experimental modules, where each module shows if the subject is in the condition of a high personal cost of reporting; the subject is in a condition of low personal cost of reporting; the subject is in the high status of wrongdoer; and the subject is in the condition of a low status of wrongdoer. The condition of high personal cost of reporting is a condition when the sanction suffered by a whistleblower is in the form of severe sanctions, namely disrespectful termination of employment. The low personal cost of reporting occurs when a whistleblower gets a minor sanction after performing whistleblowing, namely only gets a reprimand. The high status of the wrongdoer shows a high authority position of the wrongdoer indicated by the position of head of department. The low status of the wrongdoer is indicated by the low position of the wrongdoer, namely the accounting staff.

The steps that were carried out in this analysis were:

1. Presenting a descriptive statistical analysis of the experimental results.

2. Conducting a test of effectiveness of randomization using the one-way ANOVA.

The test of effectiveness of randomization is done to test if the characteristics of the subjects influence decision making. Randomization is said to be effective if the dependent variable of whistleblowing is not influenced by the independent variable, i.e. the demographic characteristics of the subjects. The test of effectiveness of randomization was accepted if the significance level of all demographic characteristics is greater than $\alpha=5 \%$.

3. Performing a manipulation check. Manipulation check is done by determining the subjects' answer score for the questions given.

4. Performing a test of hypothesis with an average difference test (independent t-test) for the first and second hypotheses, and the two- 
way ANOVA for the third hypothesis. Two way ANOVA and the independent $\mathrm{t}$-test are accepted if the significance level is less than $\alpha$ $=5 \%$.

\section{RESULTS AND DISCUSSION}

\section{General Description of Subjects}

The subjects of this study were students of an accounting study program who had taken an auditing course. The subjects came from the Universitas Widya Mandala Surabaya (51 subjects) and Universitas Atma Jaya Yogyakarta (47 subjects). Students were used as subjects because they do not require basic experience and knowledge in this experimental method. Those who took part in the simulation were 98 students. However, after performing a manipulation check, the subjects who passed the manipulation amounted to 95. In this simulation, the subject acted as the government's internal auditor. Table 2 shows the characteristics of the subjects involved in the study.

Table 2: Demographic Characteristics of Subjects

\begin{tabular}{lccc}
\hline \multicolumn{1}{c}{ Demography Characteristics } & $\begin{array}{c}\text { Number of } \\
\text { Subject }\end{array}$ & Percentage (\%) \\
\hline Gender & Male & 22 & 23,16 \\
& Female & 73 & 76,84 \\
Grade Point Average & $\leq 3$ & 20 & 21,05 \\
(GPA) & $3-3,5$ & 39 & 41,06 \\
& $\geq 3,5$ & 36 & 37,89 \\
Semester & 6 & 90 & 94,74 \\
& 8 & 5 & 5,26 \\
\hline
\end{tabular}

Table 2 shows that the majority of subjects who participated in the simulation were female with a total of 73 students $(76.84 \%)$ and the majority GPA was in the range of 3-3.5 (41.06\%). The average subjects who followed the audit simulation were in semester 6 and only 5 students $(5.26 \%)$ were in semester 8 . 


\section{Manipulation Check}

The manipulation check was done by giving the subjects three questions about their current condition based on the module. If the subjects answered at least two questions correctly, it was concluded that they passed the manipulation. The analysis results of manipulation checks showed that out of 98 subjects, 3 subjects (3.06\%) did not pass the manipulation check, while the subjects who passed were 95 students (96.94\%).

\section{Randomization Test}

Before testing the hypotheses, a test of randomization needs to be firstly done. Randomization test aims to determine whether demographic factors influence the subjects' decision making. A randomization test was carried out by testing demographic factors on the subjects' characteristics on judgment by using the one way ANOVA. Randomization was accepted if the dependent variable was the intention to perform whistleblowing was not influenced by demographic characteristics.

Table 3: Results of Test of Randomization Effectiveness

\begin{tabular}{lcc} 
& F-Statistics & Sig. \\
\hline Gender & 0,722 & 0,633 \\
Grade Point Average (GPA) & 1,050 & 0,399 \\
Semester & 1,794 & 0,109 \\
General Knowledge & 0,809 & 0,565 \\
\hline
\end{tabular}

The results of the randomization test in this study indicated that there was no influence between the decisions to perform whistleblowing with the subjects' demographic characteristics. Table 3 shows that all the levels of significance of demographic characteristics were more than 0.05 (0.633; $0.399 ; 0.109 ; 0.565)$. This means that the three demographic indicators which include gender, grade point average, semester, and general knowledge did not affect the decision to perform whistleblowing. Therefore, the results of randomization test are said to be effective because demographic factors do not affect the subjects' decision and that only the manipulation treatment affects the subjects' decision. 


\section{Test of Hypotheses}

\section{Test of hypothesis 1}

Hypothesis 1 in this study postulated that subjects with a condition of high personal cost of reporting will have a lower intention to perform whistleblowing than subjects with a condition of low personal cost of reporting. Hypothesis 1 test was done using the independent sample t-test.

Table 4: Results of Hypothesis Test 1

\begin{tabular}{lcccc}
\hline & Mean & $\begin{array}{c}\text { Std. } \\
\text { Deviation }\end{array}$ & T & $\begin{array}{c}\text { Sig. } \\
\text { (2-tailed) }\end{array}$ \\
\hline High Personal Cost of Reporting & 79,78 & 16,718 & $-4,038$ & 0,000 \\
Low Personal Cost of Reporting & 91,20 & 10,428 & & \\
\hline
\end{tabular}

Statistics test shows significant results that there is a difference in intention of whistleblowing between subjects in a condition of high and low personal cost of reporting at a $\alpha=5 \%$ significance level of ( $\operatorname{sig} 0,000$ $<0,05)$. This difference also proves that the subjects' intention to perform whistleblowing on a condition of high personal cost of reporting will be lower than the subjects on a condition of low personal cost of reporting. The average result of high personal cost of reporting was at 79.78 while on low personal cost of reporting was at 91.20. This shows that subjects who were in a condition of low personal cost of reporting tended to have a higher fraudulent intention than subjects who received a condition of high personal cost of reporting.

This result is in accordance with the theory of planned behavior which states that the sanction to be accepted is one of considerations for carrying out whistleblowing. People's intention to take action is weaker when they feel that they will get a disadvantage from their action. One who is encountered with a condition of obtaining only a reprimand, will make a decision to do whistleblowing. On the contrary, when one encounters a possible severe sanction tends to choose to stay silent.

The results of this study are in line with the research of Nickolan, Lilik Handajani, and Hermanto (2018) who conducted a study on the personal cost of reporting toward auditors of the Indonesian government and found that the personal cost of reporting influenced the intention to perform 
whistleblowing. Personal cost of reporting can be in the form of reprimand, demotion, or even disrespectful dismissal. However, this result is different from the research of (Craft, 2013) and Alleyne et al. (2013) who found that the personal cost of reporting did not affect an auditor's intention to perform whistleblowing. The reason is that practitioners of auditing must be professional and independent.

\section{Test of hypothesis 2}

Hypothesis 2 in this study postulated that subjects with a high status of wrongdoer will have a lower intention to perform whistleblowing than subjects with a low status of wrongdoer. Similar to hypothesis 1, hypothesis 2 also used the independent sample t-test. Table 5 shows the results of hypothesis 2 testing.

Table 5: Test Results of Hypothesis 2

\begin{tabular}{lcccc} 
& Mean & Std. Deviation & T & $\begin{array}{c}\text { Sig. } \\
\text { (2-tailed) }\end{array}$ \\
\hline High Status of Wrongdoer & 79,57 & 13,825 & $-3,418$ & 0,001 \\
Low Status of Wrongdoer & 88,75 & 12,312 & & \\
\hline
\end{tabular}

The results of statistical test as in Table 5 show that there are differences in the intention of whistleblowing between subjects with a high wrongdoer status condition and subjects with a low status of wrongdoer at the $\alpha=5 \%$ significance level (sig $0.001<0.05$ ). The intention of subjects to perform whistleblowing is lower when they deal with the condition of a high status of wrongdoer than subjects in the condition of a low status of wrongdoer. This can be seen through the results of the average score of a high wrongdoer status which amounted to 79.57 while the subjects in the condition of a low wrongdoer status amounted to 88.75 . This shows that subjects who encountered the condition of a low status of wrongdoer tend to have higher fraudulent intention than subjects who encountered a condition of a high status of wrongdoer.

One of categories in the theory of planned behavior is the control of behavior which states that a person's actions depend on the easiness or difficulty that they will encounter (Ajzen, 2011). The authoritative position of the wrongdoer has become a consideration for a whistleblower in performing whistleblowing. If the position of the wrongdoer is higher, it is 
increasingly difficult for a whistleblower to disclose fraud. The higher the position of the wrongdoer, the easier it is to find out who reported a fraud. The organizational structure that places the Regional Inspectorate under the Regional Head and technically under the Regional Secretary allows a higher level of retaliation risk when someone reports a fraud. It will reduce the whistleblower's intention to perform whistleblowing.

These results are in line with the research of Morrison (2011), Kaptein (2011), Cho and Perry (2012), and Nickolan, Lilik Handajani, and Hermanto (2018) who stated that the high status of the wrongdoer will make it difficult for those in a lower position because they will receive undue treatment. Organizations tend to depend and protect employees with high positions. The results of this study are different from the research of Suyatno, Armstrong and Thomas (2017) who found that the position of a wrongdoer did not affect the intention of whistleblowing.

\section{Test of hypothesis 3}

Hypothesis 3 in this study postulated that subjects with the condition of a high personal cost of reporting and a high status of wrongdoer will have a low intention of whistleblowing compared to subjects with the condition of a low personal cost of reporting and a low status of wrongdoer. Test of hypothesis 3 was done by the two-way ANOVA test.

Table 6: Test Results of Hypothesis 3

\begin{tabular}{lcccccc}
\hline \multicolumn{5}{c}{ Tests of Between - Subjects Effects } \\
Dependent Variable : Intention of Whistleblowing & & \\
\hline \multicolumn{1}{c}{ Source } & $\begin{array}{c}\text { Type III Sum } \\
\text { of Squares }\end{array}$ & df & $\begin{array}{c}\text { Mean } \\
\text { Square }\end{array}$ & F & Sig. \\
\hline Corrected Model & 2119,474 & 3 & 706,491 & 3,171 & 0,028 \\
Intercept & 629538,309 & 1 & 629538,309 & 2825,365 & 0,000 \\
Status of Wrongdoer & 533,558 & 1 & 533,558 & 2,395 & 0,125 \\
Personal Cost of Reporting & 308,754 & 1 & 308,754 & 1,386 & 0,242 \\
Status of Wrongdoer * & 1153,385 & 1 & 1153,385 & 5,176 & 0,025 \\
Personal Cost of Reporting & & & & & \\
Error & 20276,315 & 91 & 222,817 & & \\
Total & 657900,000 & 95 & & & \\
Corrected Total & 22395,789 & 94 & & & \\
\hline
\end{tabular}


The statistical test in Table 6 shows a significance level 0.025 or lower than 0.05 . This shows that the third hypothesis in this study is supported. Table 7 shows that the group average scores in the condition of a low personal cost of reporting and a low status of wrongdoer have an average value of 89.2308. This value is greater than value in the condition of a high personal cost of reporting and a high status of wrongdoer which is only equal to 80.8696. Based on these data, it can be concluded that the intention of someone's whistleblowing will be higher when he is in a low personal cost of reporting and a low status of wrongdoer condition compared to a high condition of personal cost of reporting and a high status of wrongdoer.

Table 7: Descriptive Statistics of Hypothesis 3

\begin{tabular}{ccccc}
\hline \multicolumn{4}{c}{} & \multicolumn{2}{c}{ Descriptive Statistics } & \\
Dependent Variable: Intention of Whistleblowing & \\
Srongdoer & $\begin{array}{c}\text { Personal Cost of } \\
\text { Reporting }\end{array}$ & Mean & $\begin{array}{c}\text { Std. } \\
\text { Deviation }\end{array}$ & N \\
\hline High & High & 80,8696 & 15,34839 & 23 \\
& Low & 77,5000 & 14,21879 & 24 \\
& Total & 79,1489 & 14,71908 & 47 \\
Low & High & 78,6364 & 18,33432 & 22 \\
& Low & 89,2308 & 11,63549 & 26 \\
& Total & 84,3750 & 15,83240 & 48 \\
Total & Tinggi & 79,7778 & 16,71810 & 45 \\
& Low & 83,6000 & 14,10746 & 50 \\
& Total & 81,7895 & 15,43545 & 95 \\
\hline
\end{tabular}

The results show that the personal cost of reporting and the status of the wrongdoer have an effect on one's intention to perform whistleblowing. Based on the theory of planned behavior, one's actions are based on consideration of advantages or disadvantages and easiness or difficulty that will be faced (Ajzen, 2011). A whistleblower prefers not to perform whistleblowing when the wrongdoer has a higher position and sanctions to be received are severe. Retaliation is a component of the personal cost of reporting. A whistleblower who reports fraudulent action committed by a wrongdoer with a higher authority will face increasingly severe sanctions. Therefore, the higher the status of the wrongdoer, the higher the personal cost of reporting which will be received by the informant and will reduce his intention to perform whistleblowing. 
The research of Nickolan, Handajani, and Hermanto (2018) examined the effect of personal cost of reporting and status of the wrongdoer towards Indonesian government auditors support the results of this study. Employees who have a high position will find it easier to find out who reports the fraud. Being in this authoritative position, will make it easier to retaliate on the whistleblower.

\section{CONCLUSION, IMPLICATION, AND LIMITATIONS}

\section{Conclusion}

The results of this study show that the personal cost of reporting and the status of wrongdoer affect the intention to perform whistleblowing. Someone in a high personal cost of reporting tends to have a low intention to perform whistleblowing compared to someone in a low condition of personal cost of reporting. The high status of the wrongdoer will make it difficult to be reported compared to the low status of wrongdoer, which will reduce the intention of whistleblowing. In addition, the interaction between the personal cost of reporting and the status of the wrongdoer has a significant effect on the intention to perform whistleblowing. Someone's intention for whistleblowing will be higher when he is in a low condition of personal cost of reporting and low status of wrongdoer compared to a high condition of personal cost of reporting and a high status of wrongdoer.

\section{Implications}

\section{Knowledge implications}

Through this paper, auditors of public organizations can become aware of matters relating to whistleblowing intentions. Factors that may increase or reduce someone's whistleblowing intention are made known. Thus, auditors are able to minimize fraud through increased whistlebowing.

\section{Theoretical implications}

The theoretical implication of this study is that it provides evidence that if the personal cost of reporting is related to the status of wrongdoer, it can affect the intention of whistleblowing. This study contributes to the development of behavioral research in examining the personal cost of reporting and status of the wrongdoer. 


\section{Practical implications}

This study calls for organizations to pay more attention on the mechanism of whistleblowing. This can be done by implementing a whistleblowing system that makes it easy for the reporting process, protects the security of fraudulent informants, and imposes no sanctions against whistleblowers. Thus, fraud in organizations can be reduced by implementing such a system.

\section{Limitations and Suggestions}

The limitation of this study lies in the number of subjects. There were more than 50 subjects in a single room at the time of filling out of the modules. This causes the filling out of modules to be difficult to control. For further research, it is proposed that researchers pay more attention to the number of subjects in a single room, having about 25 subjects will make it easy to control filling of the modules. In addition, future research may consider individual characteristics such as Machiavelli and organizational climate.

\section{REFERENCES}

ACFE. (2018). Report to the nations (pp. 1-80). Retrieved from ACFE website: https://s3-us-west-2.amazonaws.com/acfepublic/2018-reportto-the-nations.pdf

Ajzen, I. (2011). The theory of planned behaviour: Reactions and reflections. Psychology \& Health, 26(9), 1113-1127.

Alleyne, P., Hudaib, M., \& Pike, R. (2013). Towards a conceptual model of whistle-blowing intentions among external auditors. The British Accounting Review, 45(1), 10-23.

Bjørkelo, B., Einarsen, S., Nielsen, M. B., \& Matthiesen, S. B. (2011). Silence is golden? characteristics and experiences of self-reported whistleblowers. European Journal of Work and Organizational Psychology, 20(2), 206-238. 
Cho, Y. J., \& Perry, J. L. (2012). Intrinsic motivation and employee attitudes role of managerial trustworthiness, goal directedness, and extrinsic reward expectancy. American Society for Public Administration, 32(4), 382-406.

Craft, J. L. (2013). A review of the empirical ethical decision-making literature: 2004-2011. Journal of Business Ethics, 117(2), 221-259.

DJPP. (2010). Peraturan Pemerintah No 53 Tahun 2010 tentang Disiplin Pegawai Negeri. Retrieved 20 November 2018, from Peraturan.go.id website: http://peraturan.go.id/pp/nomor-53-tahun-2010-11e44c4f2dd 48870a1fc313231393238.html

ERC. (2013). National business ethics survey of the U.S. workforce. Retrieved from Ethics Resource Center website: http://lowellmilkeninstitute. law.ucla.edu/wp-content/uploads/2015/10/Thomas-Jordan_EthicsResource-Center-National-Business-Ethics-of-the-U.S.-Workplace.pdf

Fragale, A. R., Overbeck, J. R., \& Neale, M. A. (2011). Resources versus respect: Social judgments based on targets' power and status positions. Journal of Experimental Social Psychology, 47(4), 767-775.

Gao, J., Greenberg, R., \& Wong-On-Wing, B. (2014). Whistleblowing intentions of lower-level employees: the effect of reporting channel, bystanders, and wrongdoer power status. Journal of Business Ethics, 126(1), 85-99.

Gao, L., \& Brink, A. G. (2017). Whistleblowing studies in accounting research: a review of experimental studies on the determinants of whistleblowing. Journal of Accounting Literature, 38, 1-13.

Gottschalk, P. (2011). White collar crime prevention: The role of accounting. Journal of Forensic \& Investigate Accounting, 3(1), 23-48.

Kaplan, S. E., Pope, K. R., \& Samuels, J. A. (2010). The effect of social confrontation on individuals' intentions to internally report fraud. Behavioral Research in Accounting, 22(2), 51-67. 
Kaptein, M. (2011). From inaction to external whistleblowing: The influence of the ethical culture of organizations on employee responses to observed wrongdoing. Journal of Business Ethics, 98(3), 513-530.

KPK. (2018). Impact of corruption on government bureaucracy. Retrieved 28 September 2018, from Anti-Corruption Education Center website: https://aclc.kpk.go.id/materi/bahaya-dan-dampak-korupsi/infografis/ dampak-korupsi-terhadap-birokrasi-pemerintahan.

Kummer, T. F., Singh, K., \& Best, P. (2015). The effectiveness of fraud detection instruments in not-for-profit organizations. Managerial Auditing Journal, 30(4/5), 435-455.

Morrison, E. W. (2011a). Employee voice behavior: integration and directions for future research. Academy of Management Annals, 5(1), 373-412.

Nickolan, F., Handajani, L., \& Hermanto. (2018). Whistleblowing intention of Indonesian Government Internal Auditor (APIP) and anonymous reporting channel interactions. International Journal of Economics, Commerce and Management, 6(2), 161-175.

Seda, M., \& Kramer, B. K. P. (2015). A comparison of U.S. forensic accounting programs with the national institute of justice funded model curriculum. Journal of Forensic \& Investigative Accounting, $7(2), 144-177$.

Sonnier, B. M. (2013). The effects of wrongdoer motivation and internal versus external reporting channel on the intention to report fraud. Journal of Forensic \& Investigative Accounting, 5(2), 77-133.

Suyatno, B., Armstrong, A. F., \& Thomas, K. (2017). Barriers to whistleblowing intentions and reporting channel preferences. Economic and Social Development, 115-128.

Taras, V., Kirkman, B. L., \& Steel, P. (2010). Examining the impact of culture's consequences: a three decade, multi-level, meta-analytic review of hofstede's cultural value dimensions. Journal of Applied Psychology, 95(3), 405-439. 
Wismabrata, M. H. (2018, September 4). Kasus korupsi massal di DPRD Kota Malang Ini sejumlah faktanya. Retrieved 7 October 2018, from Kompas. com website: https://regional.kompas.com/read/2018/09/04/15100021/ kasus-korupsi-massal-di-dprd-kota-malang-ini-sejumlah-faktanya. 